\title{
Inductors of Resistance and Their Role in Photosynthesis and Antioxidant System Activity of Coffee Seedlings
}

\author{
Luiz Henrique Monteiro Fernandes ${ }^{1}$, Helbert Rezende de Oliveira Silveira ${ }^{2 *}$, \\ Kamila Rezende Dázio de Souza ${ }^{3}$, Mário Lúcio Vilela de Resende ${ }^{1}$, José Donizeti Alves ${ }^{3}$ \\ ${ }^{1}$ Department of Plant Pathology, Federal University of Lavras-UFLA, Lavras, Brazil \\ ${ }^{2}$ Agricultural Reasearch Company of Minas Gerais-EPAMIG, Campus of Federal University of Lavras-UFLA, \\ Lavras, Brazil \\ ${ }^{3}$ Department of Biology, Federal University of Lavras-UFLA, Lavras, Brazil \\ Email: ${ }^{\text {helbert rezende@yahoo.com.br }}$
}

Received 9 October 2014; revised 16 November 2014; accepted 28 November 2014

Copyright (C) 2014 by authors and Scientific Research Publishing Inc.

This work is licensed under the Creative Commons Attribution International License (CC BY). http://creativecommons.org/licenses/by/4.0/

(c) (i) Open Access

\begin{abstract}
We investigated the effects of formulations based on phosphite products on gas exchange and activity of antioxidant enzymes in coffee plants. Seedlings of the Mundo Novo cultivar were submitted to various treatments composed of different formulations of with potassium phosphite (ADB 120), manganese phosphite (Reforce Mn), and fungicide (PrioriXtra ${ }^{\circledR}$ ). For coffee seedlings, the combination of potassium phosphite and citrus by-products, isolated or in a combination with other products elicited the antioxidant system. Besides the high activity of antioxidant enzymes, the photosynthetic rates were higher than other treatments. The better performance of coffee seedlings treated with those formulations occurred even in absence of pathogens.
\end{abstract}

\section{Keywords}

Coffea arabica, Superoxide Dismutase, Ascorbate Peroxidase, Catalase

\section{Introduction}

Coffee production can be affected by biotic and abiotic factors that negatively influence yield and increase production costs. Among these factors there are high temperatures, drought, and diseases, mainly caused by fungi such as coffee rust and brown eyespot diseases [1]. Various management techniques such as afforestation, high

*Corresponding author.

How to cite this paper: Fernandes, L.H.M., de Oliveira Silveira, H.R., de Souza, K.R.D., de Resende, M.L.V. and Alves, J.D. (2014) Inductors of Resistance and Their Role in Photosynthesis and Antioxidant System Activity of Coffee Seedlings. American Journal of Plant Sciences, 5, 3710-3716. http://dx.doi.org/10.4236/ajps.2014.525387 
plant density, and irrigation have been developed to alleviate the problems caused by high temperatures and drought [2]. However, the treatment of coffee diseases is more challenging, relying on the application of chemicals, mainly fungicides, of which very few are commercially available [3].

One potential alternative to fungicides is the use of resistance inductors (elicitors) that respond to biotic and abiotic agents [4] [5]. Resistance inductors include phosphites and formulations based on plant extracts and by-products of plant agroindustries. When applied to plant leaves, phosphites can control diseases by two separate mechanisms: by directly affecting the pathogen and/or by activating the plant defense responses [6].

Plant response against pathogen is related to different physiological mechanisms such as generation of reactive oxygen species generation [7], changes in cell wall thickness, deposition of callose [8], increase in compounds of secondary metabolism [9] [10], and stimulation of networks controlled by plant hormones [11].

Phosphites are inductors of resistance in plants as they stimulate plant mechanisms of defense [8] [12]. Those compounds based on phosphites formulations have been used in defense against plant pathogens from genus such as Phytophora, Fusarium, Rhizoctonia, Erwinia, Peronospora, Plasmopora [8] [13]-[15] in different plant species.

Phosphites application in plants for induction of resistance is related to changes in pectin levels and in activity of enzymes related to the cell wall structure [16]; increases in activity of enzymes like phenylalanine ammonialyase that are involved in cellular defense and increases in synthesis of phenolic compounds [17]. There is also an increase in reactive species generation [8] and in the expression of genes related to the production the hormones ethylene, salycilic acid and jasmonic acid [18].

Many studies have been developed about the processes of resistance induction against pathogens by products based on phosphite formulations. Moreover, the mecanisms of induction of resistance and the changes promoted by phosphites are well known in plants under pathogen infestations. Nevertheless, there is a lack of works describing physiological changes induced by phosphites in plants in the absence of pathogens. In this study, we investigated the effects of formulations based on phosphite products on gas exchange and activity of antioxidant enzymes in coffee plants.

\section{Material and Methods}

The experiment was performed using 6-month-old seedlings of Coffea arabica L., cultivar Mundo Novo IAC 379-19. The seedlings were maintained in $\mathrm{CO}_{2}$ concentrations of $405.51 \pm 2.53$ VPM (volume per million) and $60 \%$ humidity. The treatments were applied by hand sprayer, and gas exchange and harvesting for biochemical analyses were performed 7, 14, 21, and 28 days after spraying (DAS).

Treatment formulations were composed of isolates or mixtures (see Table 1) of manganese phosphate- $\mathrm{P}_{2} \mathrm{O}_{5}$ and Mn (Reforce Mn; Agrichem ${ }^{\circledR}$ ), a fungicide (PrioriXtra ${ }^{\circledR}$, which contains cyproconazole and azoxystrobin, Syngenta ${ }^{\circledR}$ ) and potassium phosphite with citrus pulp residues (ADB 120, Agrichem ${ }^{\circledR}$ ).

Ecophysiological evaluations were performed on the third and fourth fully expanded pair of leaves with the LI-6400XT Portable Photosynthesis System (LI-COR, Lincoln, USA). The evaluated parameters were: photosynthetic leaf rate (A), intercellular $\mathrm{CO}_{2}$ concentration (Ci), atmospheric $\mathrm{CO}_{2}$ concentration (Ca), stomatal conductance (gs), and transpiration (E). Carboxylation efficiency (CE) and water-use efficiency (WUE) were obtained

Table 1. Description of the treatments and doses used in the experiments.

\begin{tabular}{|c|c|c|}
\hline \multicolumn{2}{|r|}{ Treatments } & \multirow{2}{*}{ Composition } \\
\hline $\mathrm{T} 1$ & Control & \\
\hline $\mathrm{T} 2$ & Reforce Mn $\left(3.0 \mathrm{~L} \cdot \mathrm{ha}^{-1}\right)$ & Manganese phosphite \\
\hline $\mathrm{T} 3$ & $\operatorname{PrioriXtra}^{\circledR}\left(0.5 \mathrm{~L} \cdot \mathrm{ha}^{-1}\right)$ & Fungicide \\
\hline $\mathrm{T} 4$ & $\begin{array}{l}\text { Reforce Mn }\left(3.0 \mathrm{~L} \cdot \mathrm{ha}^{-1}\right)+\text { PrioriXtra }^{\circledR} \\
\left(0.5 \mathrm{~L} \cdot \mathrm{ha}^{-1}\right)\end{array}$ & Manganese phosphite + Fungicide \\
\hline T5 & $\begin{array}{l}\text { ADB } 120\left(3.0 \mathrm{~L} \cdot \mathrm{ha}^{-1}\right)+\text { Reforce Mn } \\
\left(3.0 \mathrm{~L} \cdot \mathrm{ha}^{-1}\right)+\text { PrioriXtra }^{\circledR}\left(0.5 \mathrm{~L} \cdot \mathrm{ha}^{-1}\right)\end{array}$ & $\begin{array}{l}\text { Potassium phosphite plus citrus pulp residues + Manganese phosphite + } \\
\text { Fungicide }\end{array}$ \\
\hline T6 & 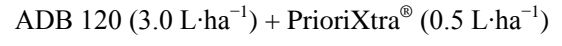 & Potassium phosphite plus citrus pulp residues + Fungicide \\
\hline $\mathrm{T} 7$ & $\operatorname{ADB} 120\left(3.0 \mathrm{~L} \cdot \mathrm{ha}^{-1}\right)+$ Reforce Mn $\left(3.0 \mathrm{~L} \cdot \mathrm{ha}^{-1}\right)$ & Potassium phosphite plus citrus pulp residues + Manganese phosphite \\
\hline $\mathrm{T} 8$ & 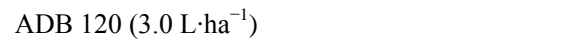 & Potassium phosphite plus citrus pulp residues \\
\hline
\end{tabular}


from ratios of $\mathrm{Ci} / \mathrm{Ca}$ and $\mathrm{A} / \mathrm{E}$, respectively. All evaluations were performed between 9 and 10 am with an artificial source of photosynthetic active radiation (PAR) in a chamber with $1000 \mu \mathrm{mol}$ photons $\mathrm{m}^{-2} \cdot \mathrm{s}^{-1}$ (Blue + Red LED LI-6400-02B, LI-COR, Lincoln, USA).

The biochemical analyses were performed on the third and fourth fully expanded pair of leaves, which were frozen in liquid nitrogen and stored in an ultra freezer. For enzyme extraction, an extraction buffer (100 mM potassium phosphate $\mathrm{pH}$ 7.8, $0.1 \mathrm{mM}$ EDTA, $1 \mathrm{mM}$ ascorbic acid) was added to $200 \mathrm{mg}$ of the ground sample. The homogenized samples were then centrifuged at $13,000 \mathrm{~g}$ at $4^{\circ} \mathrm{C}$ for $20 \mathrm{~min}$. Supernatants were collected and used for superoxide dismutase (SOD), catalase (CAT), and ascorbate peroxidase (APX) analyses [19].

SOD activity was quantified as the ability to inhibit the photoreduction of nitroblue tetrazolium (NBT) according to [20]. CAT activity was evaluated by decreasing absorbance at $240 \mathrm{~nm}$ at $28^{\circ} \mathrm{C}$ for $3 \mathrm{~min}$ [21]. APX activity was evaluated as described by [22].

A split plot design was used with four replicates and eight treatments with four time-points evaluated (7, 14, 21, and 28 DAS). The experimental unit was composed of four plants. Statistical analyses were performed using the SISVAR program [23] and the Scott-Knott test $(\mathrm{p}<0.05)$ was used for comparison of means.

\section{Results and Discussion}

There were no significant differences in photosynthetic rates between treatments during any of the evaluation time-points (Figure 1). However, after the second evaluation plants treated with formulations 5, 6, 7 and 8 were characterized by a higher photosynthetic rate. Plants from the other treatments showed lowered levels of photosynthesis after 14 DAS and maintained these lower levels until the final evaluation. There were no significant differences in carboxylation efficiency, transpiration, stomatal conductance, and water usage efficiency.

In the first week of the experiment, when there were no significant differences in photosynthetic rates (Figure 1), the temperature was approximately $29.5^{\circ} \mathrm{C}$. Temperature values were constant until $21 \mathrm{DAS}$, reaching approximately $32.5^{\circ} \mathrm{C}$ at 28 DAS. Vapor deficit pressure (VDP) remained constant until 14 DAS, decreasing until 28 DAS. After 14 DAS photosynthetic rates remained constant in plants submitted to the treatments 5, 6, 7, and 8, but decreased in treatments $1,2,3$, and 4 . These results suggest that the most efficient formulations for maintaining photosynthesis in coffee seedlings under variable temperatures were composed of phosphite formulations. Phosphite application in high rates was related to the increase in leaf aerea index and reduction of infestation in soybean plants infected by downy mildew [24].

The SOD, CAT, and APX enzymes showed increased activity in the second time-point, decreased in the third and increased again in the final (fourth) time-point (Figure 2). In the last three evaluations, enzyme activities

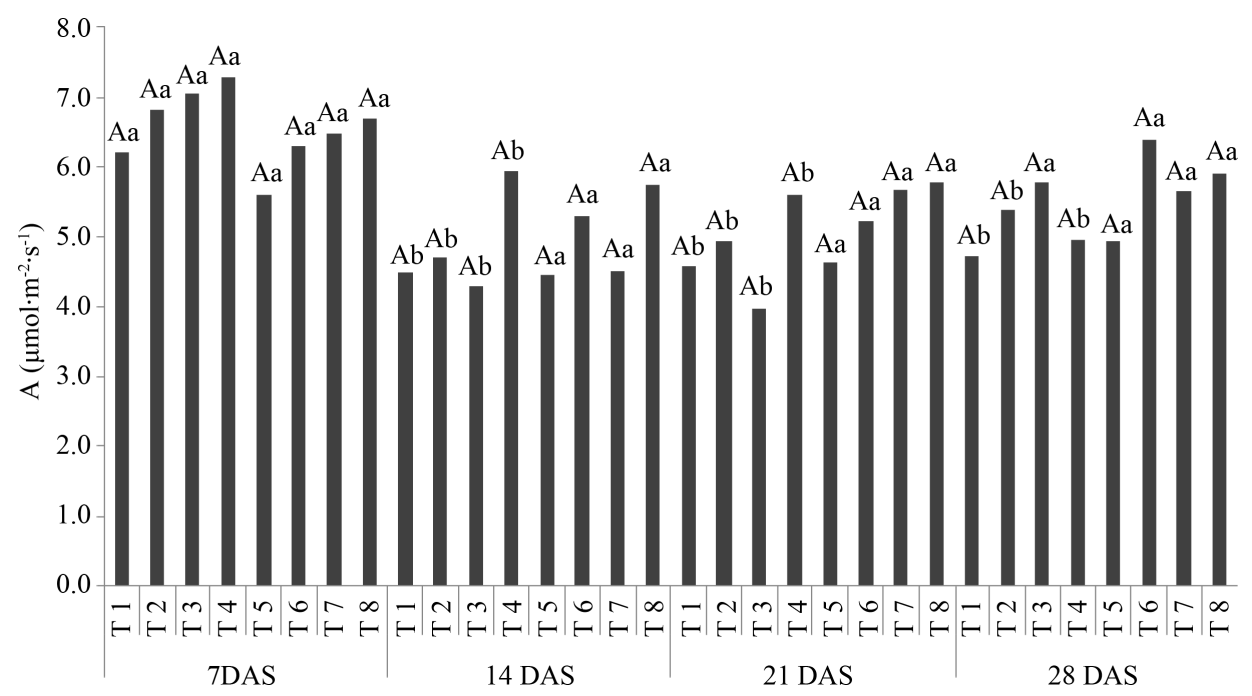

Figure 1. Net photosynthetic rate (A) of coffee seedlings at 7, 14, 21, and 28 days after spraying (DAS) with by-product of citrus agroindustry and potassium phosphite (ADB 120), manganese phosphite (Reforce $\mathrm{Mn}$ ), and fungicide (Priori Xtra ${ }^{\circledR}$ ), individually or combined. The upper case letters are comparing treatments within time-point, whereas lower case letters are comparing treatments among all time-points (Scott-Knott test at 5\% probability). 


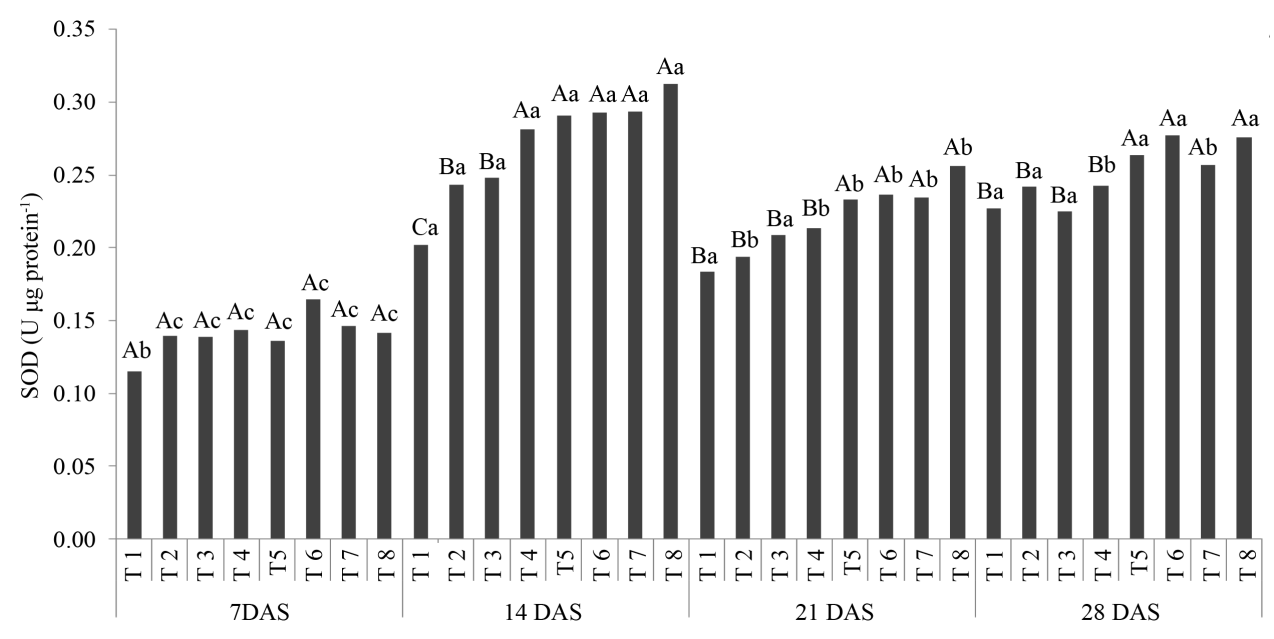

(a)

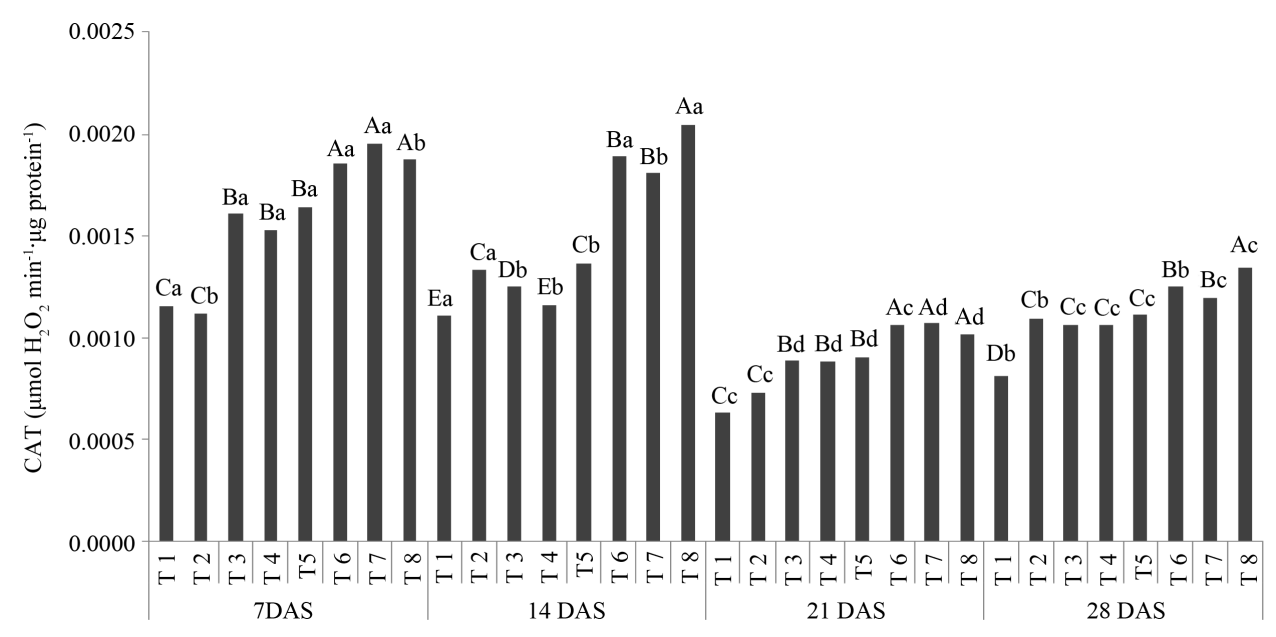

(b)

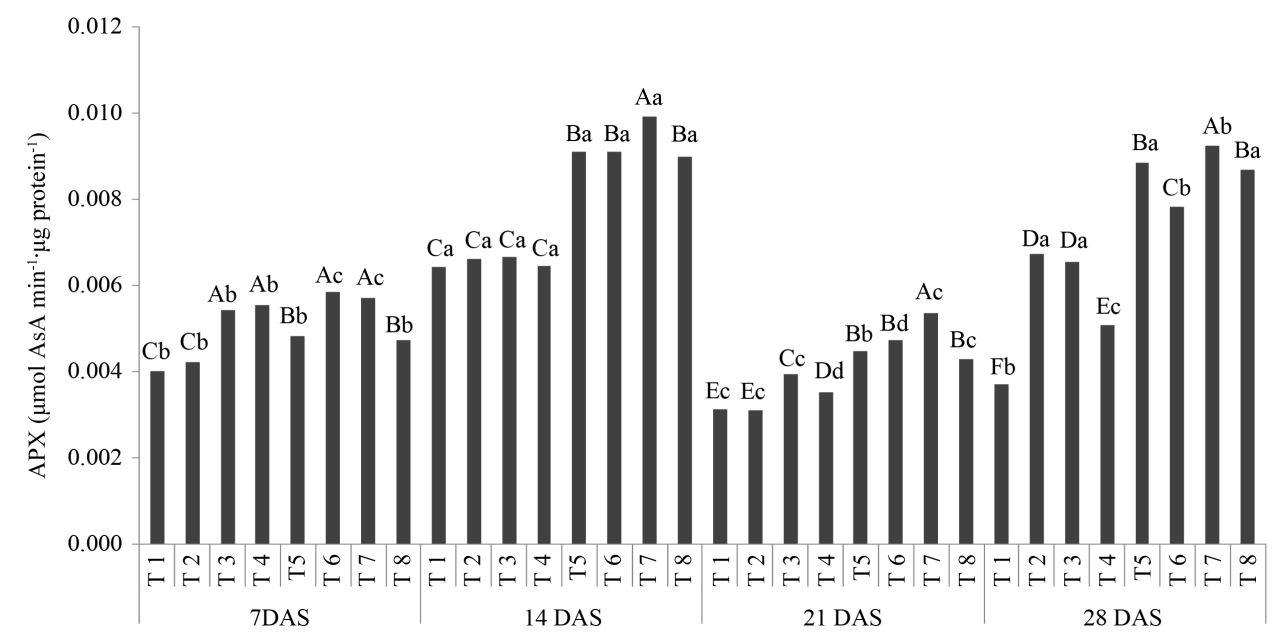

(c)

Figure 2. Activity of superoxide dismutase [SOD (a)], catalase [CAT (b)], and ascorbate peroxidase [APX (c)] of coffee seedlings at 7, 14, 21, and 28 days after spraying (DAS) with by-product of citrus agroindustry and potassium phosphite (ADB 120), manganese phosphite (Reforce Mn), and fungicide (Priori Xtra ${ }^{\circledR}$ ), individually or combined. The upper case letters are comparing treatments within time-point, whereas lower case letters are comparing treatments among all time-points (Scott-Knott test at $5 \%$ probability). 
were higher in treatments 5, 6, 7, and 8 than the other treatments.

Taking into account that citrus by-products have high levels of ascorbate, the influence of this antioxidant molecule on activity of antioxidant enzymes and photosynthesis was investigated. The activation of the antioxidant system in coffee leaves was mainly observed in plants submitted to treatments containing ADB 120, that is a combination between phosphite and citrus by-products, when applied in isolation (treatment 8) or as part of a mixture (treatments 5, 6, and 7). In these plants, oxidative stress intensified by 14 DAS by induction of SOD (Figure 2(a)), which confers cellular protection to superoxide $\left(\mathrm{O}_{2}^{--}\right)$and which generates $\mathrm{H}_{2} \mathrm{O}_{2}$ and $\mathrm{O}_{2}$. The increase in SOD activity indicates not only an increase in superoxide radicals and oxidative stress, but also the rapid involvement of the enzyme in ROS detoxification.

In plants that have an efficient antioxidant system, toxic products generated in the cell are rapidly degraded by antioxidant enzymes [25]. In this work, the $\mathrm{H}_{2} \mathrm{O}_{2}$ resulting from the reaction catalyzed by SOD was metabolized by CAT (Figure 2(b)) or APX (Figure 2(c)) in a co-regulated system. CAT catalyzes $\mathrm{H}_{2} \mathrm{O}_{2}$ in $\mathrm{O}_{2}$ and $\mathrm{H}_{2} \mathrm{O}$, whereas APX utilizes ascorbic acid as a reducing substrate and donates electrons to eliminate $\mathrm{H}_{2} \mathrm{O}_{2}$. Peroxidases are more efficient than catalase in $\mathrm{H}_{2} \mathrm{O}_{2}$ degradation, and function in a way to avoid lipid peroxidation, the main indication of oxidative damage [4]. Phosphite fertilization increased catalase activity in common beans plants in low concentrations and reduced this activity under higher concentrations [26]. In maize, phosphites stimulated eliciting biochemical responses by increasing guaiacol peroxidase activity and lignin biosynthesis [27]. In strawberry phosphites were related to higher fruit quality and stimulation of defense mechanisms by increasing anthocyanin production [28].

The coordinated action between the three enzymes observed in the plants submitted to the treatments 5, 6, 7, and 8, was essential to maintain cellular homeostasis by mitigating the damage caused by ROS. Thus, the success of the citrus by-products in resistance induction during stressful conditions can be explained, at least in part, by their ability to activate the antioxidant system of plants. In addition to antioxidant enzymes, plants have other antioxidant metabolites, such as ascorbate, which removes cytotoxic oxi-radicals and prevents damages caused by the effects of ROS [29]. In this work, the combination of potassium phosphite and citrus by-products was an external source of ascorbate, acting either directly or as a substrate for APX. In the ascorbate-glutathione cycle, the ascorbate is regenerated through the action of successive enzymes.

For coffee seedlings, the combination of potassium phosphite and citrus by products, isolated or in a combination with other products elicited the antioxidant system. Besides the high activity of antioxidant enzymes, the photosynthetic rates were higher than other treatments. The better performance of coffee seedlings treated with those formulations occurred even in absence of pathogens. In this way, the combination of potassium phosphite and citrus by products can be used to enhance the tolerance of coffee plants to pathogens.

\section{Conclusion}

Coffee seedlings sprayed with potassium phosphite combined with by-product of citrus agroindustry (isolated or combined with other products) higher antioxidant enzymatic activities and maintained photosynthetic rates even in the absence of pathogens.

\section{Acknowledgements}

We give thanks to the Fundação de Amparo à Pesquisa do Estado de Minas Gerais (FAPEMIG), Coordenação de Aperfeiçoamento de Pessoal de Nível Superior (CAPES), and Conselho Nacional de Desenvolvimento Científico e Tecnológico (CNPq) for the granting of scholarships and to Instituto Brasileiro de Ciência e Tecnologia do Café (INCT Café) by the research support.

\section{References}

[1] Cavatte, P.C., Oliveira, A.A.G., Morais, L.E., Martins, S.C.V., Sanglard, L.M.V.P. and DaMatta, F.M. (2012) Could Shading Reduce the Negative Impacts of Drought on Coffee? A Morphophysiological Analysis. Physiologia Plantarum, 144, 111-122. http://dx.doi.org/10.1111/j.1399-3054.2011.01525.x

[2] Reynol, F. (2009) As armas da ciência frente às mudanças climáticas na agricultura. Conhecimento \& Inovação, 5, 44-45.

[3] Barros, F.C., Sagata, E., Ferreira, L.C.C. and Juliatti, F.C. (2010) Indução de resistência em plantas contra fitopatógenos. Bioscience Journal, 26, 231-239. 
[4] Torres, M.A., Jones, J.D.G. and Dangl, J.L. (2006) Reactive Oxygen Species Signaling in Response to Pathogens. Plant Physiology, 141, 373-378. http://dx.doi.org/10.1104/pp.106.079467

[5] Stangarlin, J.R., Kuhn, O.J., Toledo, M.V., Portz, R.L., Schwan-Estrada, K.R.F. and Pascholati, S.F. (2011) A defesa vegetal contra fitopatógenos. Scientia Agraria Paranaensis, 10,18-46.

[6] Nojosa, G.B.A., Resende, M.L.V., Barguil, B.M., Moraes, S.R.G. and Boas, C.H.V. (2009) Efeito de indutores de resistência em cafeeiro contra a mancha de Phoma. Summa Phytopathologica, 35, 60-62. http://dx.doi.org/10.1590/S0100-54052009000100011

[7] Baxter, A., Mittler, R. and Suzuki, N. (2014) ROS as Key Players in Plant Stress Signaling. Journal of Experimental Botany, 65, 1229-1240. http://dx.doi.org/10.1093/jxb/ert375

[8] Daniel, R. and Guest, D. (2006) Defense Responses Induced by Potassium Phosphonate in Phytophthora palmivora Challenged Arabidopsis thaliana. Physiological and Molecular Plant Pathogen, 67, 194-201. http://dx.doi.org/10.1016/j.pmpp.2006.01.003

[9] Ahuja, I., Kissen, R. and Bones, A.M. (2012) Phytoalexins in Defense against Pathogens. Trends in Plant Science, 17, 73-90. http://dx.doi.org/10.1016/j.tplants.2011.11.002

[10] Miralpeix, B., Rischer, H., Hakkinen, S.T., Ritala, A., Seppanen-Laakso, T. Oksman-Caldentey, K., Capell, T. and Christou, P. (2013) Metabolic Engineering of Plant Secondary Products: Which Way Forward? Current Pharmaceutical Design, 19, 5622-5639. http://dx.doi.org/10.2174/1381612811319310016

[11] Robert-Seilaniantz, A., Grant, M. and Jones, J.D.G. (2011) Hormone Crosstalk in Plant Disease and Defense: More than Just Jasmonate-Salicylate Antagonism. Annual Review in Plant Pathology, 49, 317-343.

[12] Panicker, S. and Gangadharan, K. (1999) Controlling Downy Mildew of Maize Caused by Peronosclerospora sorghi by Foliar Sprays of Phosphonic Acid Compounds. Crop Protection, 18, 115-118. http://dx.doi.org/10.1016/S0261-2194(98)00101-X

[13] Bécot, S., Pajot, E., Le Corre, D., Monot, C. and Silué, D. (2000) Phytogard $\left(\mathrm{K}_{2} \mathrm{HPO}_{3}\right)$ Induces Localized Resistance in Cauliflower to Downy Mildew of Crucifers. Crop Protection, 19, 417-425. http://dx.doi.org/10.1016/S0261-2194(00)00034-X

[14] Lobato, M.C., Olivieri, F.P., Daleo, G.R. and Andreu, A.B. (2010) Antimicrobial Activity of Phosphites againt Different Potato Pathogens. Journal of Plant Diseases and Protection, 117, 102-109.

[15] Pinto, K.M.S., Nascimento, L.C., Gomes, E.C.S., Silva, H.F. and Miranda, J.R. (2012) Efficiency of Resistance Elicitors in the Management of Grape Vine Downy Mildew Plasmopora viticola: Epidemiological, Biochemical and Economic Aspects. European Journal of Plant Pathology, 134, 745-754. http://dx.doi.org/10.1007/s10658-012-0050-1

[16] Olivieri, F.P., Feldman, M.L., Machinandiarena, M.F., Lobato, M.C., Caldiz, D.O., Daleo, G.R. and Andreu, A.B. (2012) Phosphite Applications Induce Molecular Modifications in Potato Tuber Periderm and Cortex That Enhance Resistance to Pathogens. Crop Protection, 32, 1-6. http://dx.doi.org/10.1016/j.cropro.2011.08.025

[17] Jackson, T.J., Burgess, T., Colquhoun, I. and Hardya, G.E.StJ. (2000) Action of the Fungicide Phosphite on Eucalyptus marginata Inoculated with Phytophora cinnamomi. Plant Pathology, 49, 147-154. http://dx.doi.org/10.1046/j.1365-3059.2000.00422.x

[18] Eshraghi, L., Anderson, J., Aryamanesh, N., Shearer, B., McComb, J., Hardy, G.E.StJ. and O’Brien, P.A. (2011) Phosphite Primed Defence Responses and Enhanced Expression of Defence Genes in Arabidopsis thaliana Infected with Phytophora cinnamomi. Plant Pathology, 60, 1086-1095. http://dx.doi.org/10.1111/j.1365-3059.2011.02471.x

[19] Biemelt, S., Keetman, U. and Albrecht, G. (1998) Re-Aeration Following Hypoxia or Anoxia Leads to Activation of the Antioxidative Defense System in Roots of Wheat Seedlings. Plant Physiology, 116, 651-658. http://dx.doi.org/10.1104/pp.116.2.651

[20] Giannopolitis, C.N. and Ries, S.K. (1997) Superoxide Dismutase I. Occurrence in Higher Plants. Plant Physiology, 59, 309-314. http://dx.doi.org/10.1104/pp.59.2.309

[21] Havir, E.A. and McHale, N.A. (1987) Biochemical and Developmental Characterization of Multiple Forms of Catalase in Tobacco Leaves. Plant Physiology, 84, 450-455. http://dx.doi.org/10.1104/pp.84.2.450

[22] Nakano, Y. and Asada, K. (1981) Hydrogen Peroxide Is Scavenged by Ascorbate-Specific Peroxidase in Spinach Chloroplasts. Plant and Cell Physiology, 22, 867-880.

[23] Ferreira, D.F. (2011) Sisvar: A Computer Statistical Analysis System. Ciência e Agrotecnologia, 35, 1039-1042.

[24] Silva, O.C., Santos, H.A.A., Dalla Pria, M. and May-De Mio, L.L. (2011) Potassium Phosphite for Control of Downy Mildew of Soybean. Crop Protection, 30, 598-604. http://dx.doi.org/10.1016/j.cropro.2011.02.015

[25] Blokhina, O. and Fagerstedt, K.V. (2010) Oxidative Metabolism, ROS and NO under Oxygen Deprivation. Plant Physiology and Biochemistry, 48, 359-373. http://dx.doi.org/10.1016/j.plaphy.2010.01.007

[26] Avila, F.W., Faquin, V., da Silva Lobato, A.K., Avila, P.A., Marques, D.J., Silva Guedes, E.M. and Tan, D.K.Y. (2013) 
Effect of Phosphite Supply in Nutrient Solution on Yield, Phosphorus Nutrition and Enzymatic Behavior in Common Bean (“Phaseolus vulgaris” L.) Plants. Australian Journal of Crop Science, 7, 713-722.

[27] Avila, F.W., Faquin, V., Araujo, J.L., Marques, D.J., Junior, P.M.R., da Silva Lobato, A.K., Ramos, S.J. and Baliza, D.P. (2011) Phosphite Supply Affects Phosphorus Nutrition and Biochemical Responses in Maize Plants. Australian Journal of Crop Science, 5, 646-653.

[28] Estrada-Ortiz, E., Trejo-Téllez, L.I., Gómez-Merino, F.C., Núñez-Escobar, R. and Sandoval-Villa, M. (2013) The Effects of Phosphite on Strawberry Yield and Fruit Quality. Journal of Soil Science and Plant Nutrition, 13, 612-620.

[29] Deuner, S., Alves, J.D., Zanandrea, I., Goulart, P.F.P., Silveira, N.M., Henrique, P.C. and Mesquita, A.C. (2011) Stomatal Behavior and Components of the Antioxidative System in Coffee Plants under Water Stress. Scientia Agricola, 68, 77-85. http://dx.doi.org/10.1590/S0103-90162011000100012 
Scientific Research Publishing (SCIRP) is one of the largest Open Access journal publishers. It is currently publishing more than 200 open access, online, peer-reviewed journals covering a wide range of academic disciplines. SCIRP serves the worldwide academic communities and contributes to the progress and application of science with its publication.

Other selected journals from SCIRP are listed as below. Submit your manuscript to us via either submit@scirp.org or Online Submission Portal.
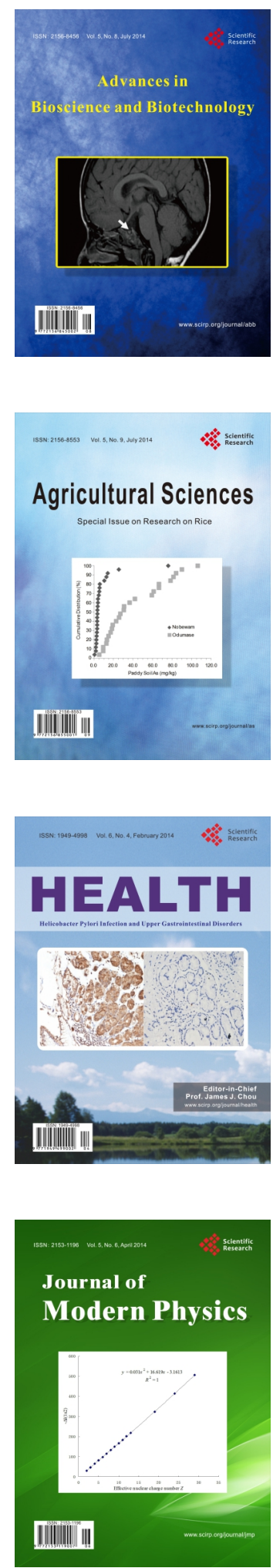
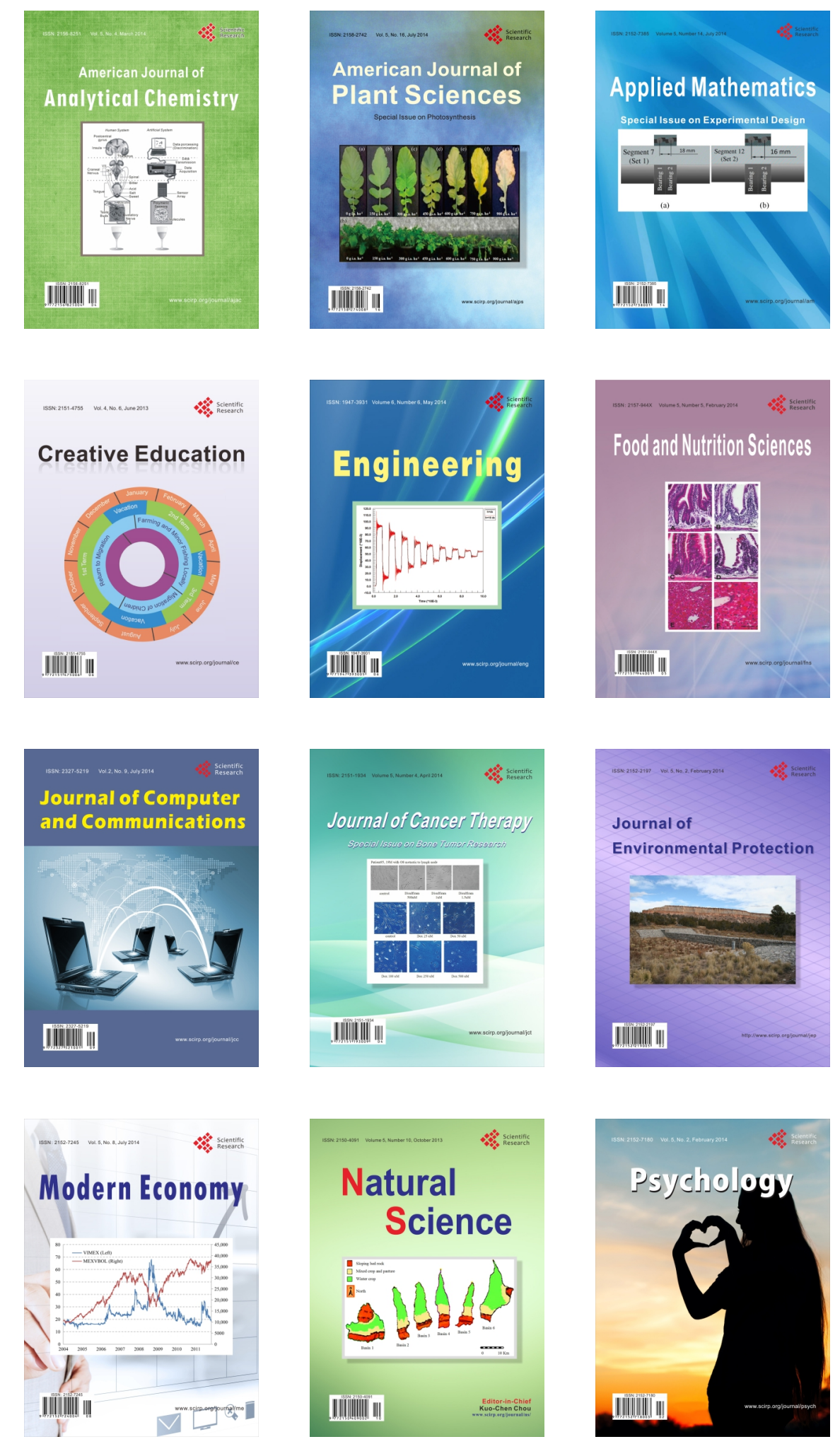